\title{
Rapid determination of the numbers of Varroa destructor, a parasitic mite of the honey bee, Apis mellifera, on sticky-board collection devices
}

\author{
Nicholas W. CALDERONE*, Sisi LIN \\ Department of Entomology, Comstock Hall, Cornell University, Ithaca, NY 14853, USA
}

(Received 21 May 2001; revised 25 March 2002; accepted 18 April 2002)

\begin{abstract}
We collected mites on boards coated with Vaseline; then, Vaseline, mites and debris were removed and solvent processed. Three weights were obtained for each sample: (1) weight after processing (pre-cleaned weight $=\mathrm{W}_{\text {pre }}$ ); (2) weight after removing most remaining contaminants (partially cleaned weight $=\mathrm{W}_{\text {par }}$ ); and (3) weight after removing all remaining contaminants (clean weight $=\mathrm{W}_{\mathrm{cln}}$ ). $\mathrm{The}$ regression of the actual number of mites on $\mathrm{W}_{\mathrm{cln}}$ was significant $(P<0.0001)$. Therefore, we evaluated the usefulness of $\mathrm{W}_{\text {pre }}$ and $\mathrm{W}_{\text {par }}$ as surrogates for $\mathrm{W}_{\mathrm{cln}}$ because they are easier to obtain. Concordance correlation coefficients $\left(r_{c}\right)$ for $\mathrm{W}_{\mathrm{cln}}$ with both $\mathrm{W}_{\text {pre }}$ and $\mathrm{W}_{\mathrm{par}}$ were $<0.80$; therefore, correction factors for the two surrogates were calculated by dividing the average value of $\mathrm{W}_{\mathrm{cln}}$ by: (1) the average value of Wpre, or (2) the average value of $\mathrm{W}_{\text {par }}$. $\mathrm{W}_{\text {pre }}$ and $\mathrm{W}_{\text {par }}$ were adjusted by multiplying them by the appropriate factor. The $r_{c}$ values for corrected data were $>0.99$. Our method lets us obtain an accurate estimate of the number of mites in 20-30 min, regardless of the number present, and is useful when the number of mites on a board $>4500$. Our method also avoids the loss of precision that occurs with sub-sampling.
\end{abstract}

Varroa destructor / Apis mellifera / population estimation

\section{INTRODUCTION}

A number of research projects with Varroa destructor Anderson \& Trueman (Acari, Varroidae), including the development of new acaricides, require the collection of mites on sticky-board collection devices. The mites must be counted; and, as there may be many thousands of mites on each board, this can take considerable time. Previous methods for reducing the time involved in counting mites rely on sub-sampling (Calderone, 1999; Ostiguy and Sammataro, 2000), but considerable time may still be required to estimate the number of mites when mite loads are high. Additionally, sub-sampling introduces error into an estimate. A method that allows for the rapid determination of the number of mites on a sticky board without sub-sampling, regardless of the number of mites present, is highly desirable. In this study, we evaluate such a method. Using a series of solvents, we separate the mites from the hive debris that accumulates on the sticky boards. Then, we estimate the number of mites on the board from the weight of the mites. Our method allows us to obtain an accurate and precise estimate of the number of all of the mites on a board in $20-30 \mathrm{~min}$, regardless of the number of mites present.

\footnotetext{
* Correspondence and reprints

E-mail: nwc4@cornell.edu
} 


\section{MATERIALS AND METHODS}

\subsection{Estimate of time required to count mites}

We used a population of 46 sticky-boards with mites to determine the relationship between the number of mites on a board and the time required to count those mites using linear regression analysis (SAS, 1988). We use this information to evaluate the efficiency of our new method, relative to other methods.

\subsection{Collection of mites}

A sticky board (Calderone et al., 1997) was coated with a thin layer of Vaseline ${ }^{\mathrm{TM}}$ (petrolatum), attached to a screened frame to prevent access by bees (Apis mellifera L.), and placed in a mite infested colony. CheckMite+ strips (10\% Coumaphos) were placed in the colony to kill mites, which were collected on the sticky board. After several days, the board was removed from the colony. The mites, accompanying debris and Vaseline were removed from the board with a single-edged razor blade and placed in a $150 \mathrm{ml}$ beaker. We added ca. $60 \mathrm{ml}$ of $1.0 \mathrm{M}$ potassium hydroxide to the beaker and brought the solution to a rolling boil. After most of the non-chitinous material was dissolved, we poured the material through a stainless steel strainer and rinsed the mites with hot tap water for about $1 \mathrm{~min}$. Next, the strainer was immersed in a beaker containing $800 \mathrm{ml}$ acetone and then in a beaker containing $800 \mathrm{ml}$ hexane (both at room temperature) to remove remaining soluble, polar and non-polar compounds. The strainer was held in each solvent for $1 \mathrm{~min}$, during which time the material was gently stirred. The remaining material was transferred to a petri dish, air dried, and weighed (0.0001 g). We repeated this procedure with 32 colonies.

\subsection{Weight of mites}

Three weights were obtained for each sample: (1) the weight after solvent processing (pre-cleaned weight $=\mathrm{W}_{\text {pre }}$ ); (2) the weight after removing the majority of remaining contaminants with fine forceps (partially cleaned weight $=\mathrm{W}_{\text {par }}$; the average amount of time required to partially clean a sample was $9.45 \pm 0.91 \mathrm{~min}$ ); and (3) the weight after separating mites from all remaining contaminants (clean weight $=\mathrm{W}_{\mathrm{cln}}$ ). We also counted the number of mites in each sample.

\subsection{Statistical analysis}

The 32 samples were randomly assigned to two groups, designated $\mathrm{A}$ and $\mathrm{B}$, each containing
16 samples. For group A, both Pearson ( $r$, SAS, $1988)$ and concordance correlation coefficients $\left(r_{c}\right.$, Lin, 1989, 1992) were calculated for $\mathrm{W}_{\mathrm{cln}}$ with $\mathrm{W}_{\text {pre }}$ and for $\mathrm{W}_{\mathrm{cln}}$ with $\mathrm{W}_{\text {par }}$. Because the $r_{c}$ values were $<0.80$, correction factors for the two surrogate estimators were calculated by dividing the average clean weight of samples $\left(\mathrm{W}_{\mathrm{cln}}\right)$ in group $\mathrm{A}$ by: (1) the average pre-cleaned weight $\left(\mathrm{W}_{\text {pre }}\right)$, or by (2) the average partially-cleaned weight $\left(\mathrm{W}_{\text {par }}\right)$ for that group. Pre-cleaned and partially cleaned weights were adjusted by multiplying them by their respective correction factors, and both Pearson and concordance correlation coefficients were re-calculated. After determining that the correction factors estimated from samples in group A raised the concordance correlation coefficients for samples in that group to $>0.99$, we tested the correction factors on the samples in group B. The entire procedure was repeated, deriving correction factors from the samples in group B and using the samples in group A as the test population. A pooled correction factor based on all 32 samples was also calculated.

\subsection{Mite weight and count}

The relationship between the actual number of mites and the clean weight of the mites was examined with standard regression analysis with the $y$-intercept set to zero (SAS, 1988).

\section{RESULTS}

\subsection{Estimate of time required to count mites}

The regression of time to count mites on a board $(y)$ on the number of mites on a board $(x)$ is shown in Figure $1\left(R^{2}=0.61 ; P<0.0001\right)$. These data allows us to determine the efficiency of our method relative to counting all mites present or using a sub-sampling method in which only a portion of the mites are counted.

\subsection{Relationship between sample weight and number of mites}

The regression of the number of mites in a sample $(y)$ on the clean weight of the sample $(x)$ was significant $\left(F_{1,32}=1509.42 ; P<\right.$ 0.0001 ; adjusted $\left.R^{2}=0.98\right)$. The estimated slope of the linear equation was $b=4329.47$ $(t=39.88 ; P<0.0001)$. 


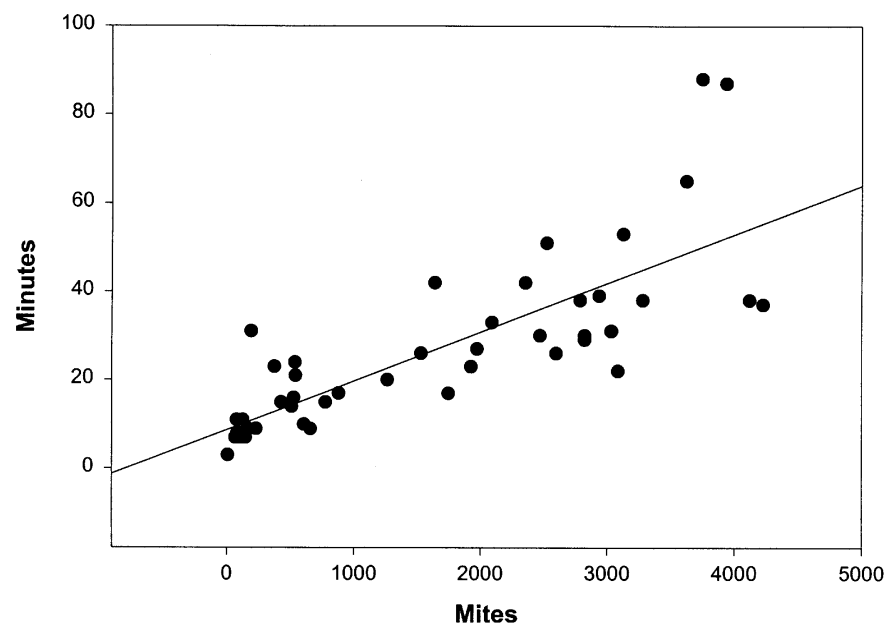

Figure 1. Regression of time to count mites (minutes) on number of mites on a board $\left(R^{2}=0.61 ; P<\right.$ 0.0001).

\subsection{Estimating correction factors from group $A$}

The averages of the uncorrected values of $\mathrm{W}_{\text {cln }}, \mathrm{W}_{\text {pre }}$ and $\mathrm{W}_{\text {par }}$ for group $\mathrm{A}$ are shown in Table IA. Correction factors estimated from the data in group $\mathrm{A}$ for $\mathrm{W}_{\text {pre }}$ and $\mathrm{W}_{\text {par }}$ are also given. Pearson and concordance correlation coefficients for groups $\mathrm{A}$ and $\mathrm{B}$ are given in Tables IIA and IIB, respectively. The $r_{c}$ values for the correlation of $\mathrm{W}_{\mathrm{cln}}$ with corrected values of $\mathrm{W}_{\text {pre }}$ and $\mathrm{W}_{\text {par }}$ were $>0.99(P<0.0001)$ for both group A and group B.

\subsection{Estimating correction factors from group $B$}

The averages of the uncorrected values of $\mathrm{W}_{\text {cln }}, \mathrm{W}_{\text {pre }}$ and $\mathrm{W}_{\text {par }}$ for group B are shown in Table IB. Correction factors estimated from the data in group $\mathrm{B}$ for $\mathrm{W}_{\text {pre }}$ and $\mathrm{W}_{\text {par }}$ are also given. Pearson and concordance correlation coefficients for groups $\mathrm{A}$ and $\mathrm{B}$ are given in Tables IIIA and IIIB, respectively. The $r_{c}$ values for the correlation of $\mathrm{W}_{\mathrm{cln}}$ with corrected values of $\mathrm{W}_{\text {pre }}$ and $\mathrm{W}_{\text {par }}$ were $>0.99(P<$ $0.0001)$ for both group A and group B.

\subsection{Pooled correction factor}

Pooled correction factors based on all 32 samples were calculated to provide a better estimate of the correction factors. The average
Table I. Average values (AVG) for pre-cleaned weights $\left(\mathrm{W}_{\text {pre }}\right)$, partially-cleaned weights $\left(\mathrm{W}_{\text {par }}\right)$ and clean weights $\left(\mathrm{W}_{\mathrm{cln}}\right)$ for uncorrected data in group A (A) and group B (B) $(\mathrm{n}=16$ in each group). All weights in grams (g). Average values for pooled data are also given (C). Correction factors were calculated by dividing $\mathrm{W}_{\mathrm{cln}}$ by either $\mathrm{W}_{\text {pre }}$ or $\mathrm{W}_{\text {par }}$

\begin{tabular}{ccc}
\hline $\begin{array}{c}\text { A. Group A } \\
\text { Variable }\end{array}$ & AVG $(\mathrm{g})$ & Correction factor \\
\hline $\mathrm{W}_{\text {pre }}$ & 1.58793 & 0.6083 \\
$\mathrm{~W}_{\text {par }}$ & 1.47737 & 0.6539 \\
$\mathrm{~W}_{\text {cln }}$ & 0.96598 & - \\
B. Group B & & \\
Variable & AVG $(\mathrm{g})$ & Correction factor \\
\hline $\mathrm{W}_{\text {pre }}$ & 1.80075 & 0.6473 \\
$\mathrm{~W}_{\text {par }}$ & 1.70934 & 0.6819 \\
$\mathrm{~W}_{\text {cln }}$ & 1.16567 & - \\
C. Pooled data & & \\
Variable & $\mathrm{AVG}(\mathrm{g})$ & Correction factor \\
\hline $\mathrm{W}_{\text {pre }}$ & 1.69434 & 0.6291 \\
$\mathrm{~W}_{\text {par }}$ & 1.59335 & 0.6689 \\
$\mathrm{~W}_{\text {cln }}$ & 1.06580 & - \\
\hline
\end{tabular}

of the uncorrected values for $\mathrm{W}_{\mathrm{cln}}, \mathrm{W}_{\mathrm{pre}}$ and $\mathrm{W}_{\text {par }}$ are shown in Table IC. Correction factors for $\mathrm{W}_{\text {pre }}$ and $\mathrm{W}_{\text {par }}$ are also given. Scatter plots of the uncorrected and corrected data are given in Figure 2. The straight lines in the graphs 
Table II. Pearson $(r)$ and concordance $\left(r_{c}\right)$ correlation coefficients for clean weights $\left(\mathrm{W}_{\mathrm{cln}}\right)$ with both uncorrected and corrected, pre-cleaned weights $\left(\mathrm{W}_{\text {pre }}\right)$ and partially-cleaned weights $\left(\mathrm{W}_{\mathrm{par}}\right)$ for groups $\mathrm{A}$ and $\mathrm{B}(* P<0.0001)$. The 95\% CI for $r_{c}$ is also given. Data were corrected using the correction factors derived from data in group A (Tab. IA).

\begin{tabular}{|c|c|c|}
\hline \multicolumn{3}{|c|}{ A. Group A - Model building } \\
\hline \multirow[t]{2}{*}{ Uncorrected data } & \multirow[b]{2}{*}{$\mathrm{W}_{\text {pre }}$} & \multirow[b]{2}{*}{$\mathrm{W}_{\text {par }}$} \\
\hline & & \\
\hline \multirow[t]{2}{*}{$\mathrm{W}_{\mathrm{cln}}$} & $r=0.964^{*}$ & $r=0.968^{*}$ \\
\hline & $r_{c}=0.702 *$ & $r_{c}=0.760^{*}$ \\
\hline $95 \% \mathrm{CI}$ for $r_{c}$ : & $0.647-0.750$ & $0.711-0.802$ \\
\hline \multicolumn{3}{|c|}{ Corrected data using correction factors derived from group } \\
\hline \multirow[t]{2}{*}{$\mathrm{W}_{\mathrm{cln}}$} & $r=0.964^{*}$ & $r=0.968^{*}$ \\
\hline & $r_{c}=0.999 *$ & $r_{c}=0.999 *$ \\
\hline $95 \%$ CI for $r_{c}:$ & 0.999-0.999 & 0.999-0.999 \\
\hline \multicolumn{3}{|c|}{ B. Group B - Model evaluation } \\
\hline \multirow[t]{2}{*}{ Uncorrected data } & & \\
\hline & $\mathrm{W}_{\text {pre }}$ & $\mathrm{W}_{\text {par }}$ \\
\hline \multirow[t]{2}{*}{$\mathrm{W}_{\mathrm{cln}}$} & $r=0.972 *$ & $r=0.976^{*}$ \\
\hline & $r_{c}=0.755^{*}$ & $r_{c}=0.796^{*}$ \\
\hline $95 \% \mathrm{CI}$ for $r_{c}$ : & $0.708-0.796$ & $0.753-0.832$ \\
\hline \multicolumn{3}{|c|}{ Corrected data using correction factors derived from group $A$} \\
\hline \multirow[t]{2}{*}{$\mathrm{W}_{\mathrm{cln}}$} & $r=0.972^{*}$ & $r=0.976^{*}$ \\
\hline & $r_{c}=0.994^{*}$ & $r_{c}=0.998^{*}$ \\
\hline $95 \% \mathrm{CI}$ for $r_{c}$ : & $0.992-0.995$ & $0.998-0.998$ \\
\hline
\end{tabular}

represent a hypothetical 1:1 correspondence between the two variables being compared. The Pearson and concordance correlation coefficients for $\mathrm{W}_{\text {cln }}$ with $\mathrm{W}_{\text {pre }}$ and $\mathrm{W}_{\text {par }}$ are given in Table IV. The $r_{c}$ values for $\mathrm{W}_{\text {cln }}$ with corrected values of $\mathrm{W}_{\text {pre }}$ and $\mathrm{W}_{\text {par }}$ were $>0.99$ $(P<0.0001)$.

\section{DISCUSSION}

We found a significant linear relationship between the number of mites in a sample and the clean weight of the sample (adjusted $R^{2}=$ $0.98 ; P<0.0001)$. This means that investigators can substitute the clean weight of mites $\left(\mathrm{W}_{\mathrm{cln}}\right)$ for the actual number of mites in the sample. However, obtaining a clean weight takes several hours, making it as tedious as counting the mites on a sticky board. Therefore we evaluated two surrogates for the clean weight of mites: pre-cleaned and partially-
Table III. Pearson $(r)$ and concordance $\left(r_{c}\right)$ correlation coefficients for clean weights $\left(\mathrm{W}_{\mathrm{cln}}\right)$ and both uncorrected and corrected, pre-cleaned weights $\left(\mathrm{W}_{\text {pre }}\right)$ and partially-cleaned weights $\left(\mathrm{W}_{\mathrm{par}}\right)$ for group A and $\mathrm{B}(* P<0.0001)$. The $95 \%$ CI for $r_{c}$ is also given. Data were corrected using the correction factors derived from data in group $\mathrm{B}$ (Tab. IB).

\begin{tabular}{lcc}
\hline \multicolumn{2}{l}{$\begin{array}{l}\text { A. Group B - Model building } \\
\text { Uncorrected data }\end{array}$} & \\
\cline { 1 - 1 } & $\mathrm{W}_{\text {pre }}$ & $\mathrm{W}_{\text {par }}$ \\
\hline $\mathrm{W}_{\mathrm{cln}}$ & $r=0.964^{*}$ & $r=0.968^{*}$ \\
& $r_{c}=0.702^{*}$ & $r_{c}=0.760^{*}$ \\
95\% CI for $r_{c}:$ & $0.650-0.750$ & $0.711-0.802$ \\
Corrected data using correction factors derived from group B \\
\hline $\mathrm{W}_{\mathrm{cln}}$ & $r=0.964^{*}$ & $r=0.968^{*}$ \\
& $r_{c}=0.991^{*}$ & $r_{c}=0.994^{*}$ \\
$95 \%$ CI for $r_{c}:$ & $0.988-0.993$ & $0.992-0.995$
\end{tabular}

B. Group A - Model evaluation

Uncorrected data

\begin{tabular}{ccc}
\hline & $\mathrm{W}_{\mathrm{pre}}$ & $\mathrm{W}_{\mathrm{par}}$ \\
\hline $\mathrm{W}_{\mathrm{cln}}$ & $r=0.972^{*}$ & $r=0.976^{*}$ \\
& $r_{c}=0.755^{*}$ & $r_{c}=0.796^{*}$
\end{tabular}

95\% CI for $r_{c}: \quad 0.708-0.796 \quad 0.753-0.832$

Corrected data using correction factors derived from group B

\begin{tabular}{lcc}
\hline $\mathrm{W}_{\mathrm{cln}}$ & $r=0.972 *$ & $r=0.976^{*}$ \\
& $r_{c}=0.999^{*}$ & $r_{c}=0.999^{*}$ \\
$95 \%$ CI for $r_{c}:$ & $0.999-0.999$ & $0.999-0.999$ \\
\hline
\end{tabular}

cleaned weights. The analysis of uncorrected weight data yielded Pearson correlation coefficients $>0.96$ in all cases; however, the corresponding concordance correlation coefficients were significantly less $\left(r_{c}<0.80\right)$. The lack of a 1:1 correspondence between $\mathrm{W}_{\mathrm{cln}}$ and $\mathrm{W}_{\text {pre }}$ and between $\mathrm{W}_{\text {cln }}$ and $\mathrm{W}_{\text {par }}$ was due primarily to scale effects, which were corrected by multiplying the original values for $\mathrm{W}_{\text {pre }}$ and $\mathrm{W}_{\text {par }}$ by correction factors. Correction factors derived from either group were shown to increase the value of $r_{c}$ from $<0.80$ to $>0.99$ for both groups. To obtain a more accurate estimate of the correction factors, we calculated values from the pooled data sets. The high concordance correlation coefficients mean that the corrected values of $\mathrm{W}_{\text {pre }}$ and $\mathrm{W}_{\text {par }}$ provide an almost perfect 1:1 correspondence with $\mathrm{W}_{\mathrm{cln}}$ and can be used as surrogates for that variable. Since the corrected value of $\mathrm{W}_{\text {pre }}$ is as accurate a surrogate as the 

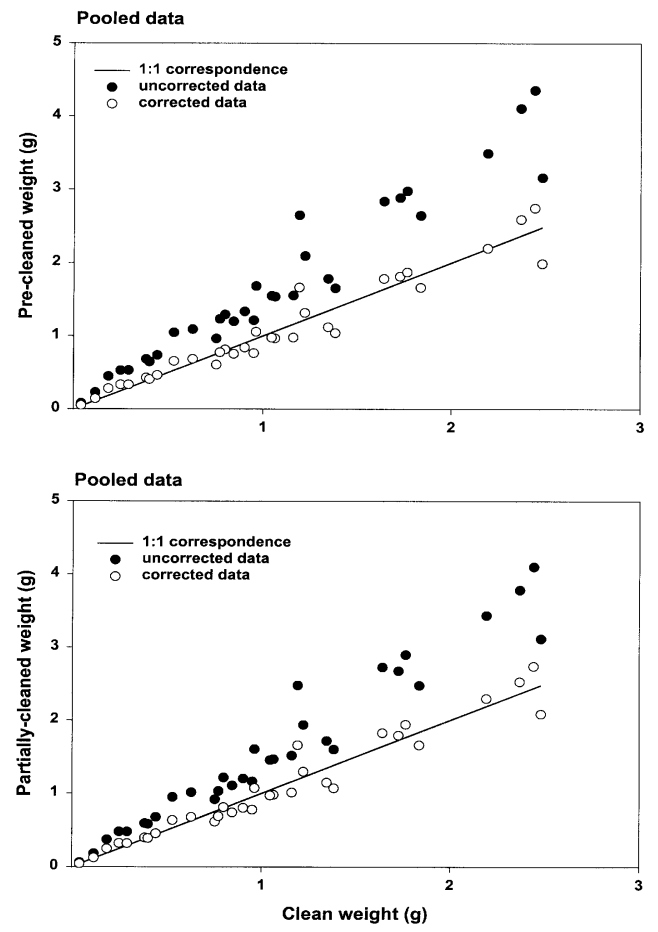

Figure 2. Scatter plots of uncorrected and corrected weight data. Corrected data are adjusted using correction factors derived from pooled data. The straight line in each graph represents a hypothetical 1:1 correspondence between the two weights. The concordance correlation coefficients $\left(r_{c}\right)$ for $\mathrm{W}_{\mathrm{cln}}$ with corrected values of $\mathrm{W}_{\text {pre }}$ and $\mathrm{W}_{\text {par }}$ were both $>0.99(P<0.0001)$.

corrected value of $\mathrm{W}_{\text {par }}$, and since it takes $<20 \mathrm{~min}$ to process a sample to the precleaned stage, regardless of the number of mites present, investigators can save considerable time by using $\mathrm{W}_{\text {pre }}$ as a measure of mite levels. Using $\mathrm{W}_{\text {par }}$ requires an additional 10 min per sample.

Our method will be useful whenever the number of mites on a board exceeds 4500 (see Fig. 1) or whenever one wishes to maximize the precision of one's estimates, regardless of mite level. We suggest using the actual precleaned or partially-cleaned weights, rather than transforming them to estimated numbers of mites using the linear equation $y=$ $4329.47 x$ derived in this study. Although this equation demonstrates a strong relationship between the clean weight of a sample and the number of mites in a sample $\left(R^{2}=0.98\right)$, the
Table IV. Pearson ( $r)$ and concordance $\left(r_{c}\right)$ correlation coefficients for clean weights $\left(\mathrm{W}_{\mathrm{cln}}\right)$ with both uncorrected and corrected, pre-cleaned weights $\left(\mathrm{W}_{\text {pre }}\right)$ and partially-cleaned weights $\left(\mathrm{W}_{\mathrm{par}}\right)$. Data from groups $\mathrm{A}$ and $\mathrm{B}$ were pooled. The $95 \% \mathrm{CI}$ for $r_{c}$ is also given $(* P<0.0001)$. Data were corrected using correction factors derived from pooled data (see Tab. IC).

\begin{tabular}{|c|c|c|}
\hline \multicolumn{3}{|c|}{ Uncorrected data } \\
\hline \multirow{3}{*}{$\mathrm{W}_{\mathrm{cln}}$} & $\mathrm{W}_{\text {pre }}$ & $\mathrm{W}_{\text {par }}$ \\
\hline & $r=0.967 *$ & $r=0.972 *$ \\
\hline & $r_{c}=0.731^{*}$ & $r_{c}=0.780^{*}$ \\
\hline $95 \% \mathrm{CI}$ for $r_{c}:$ & $0.681-0.775$ & $0.735-0.819$ \\
\hline \multicolumn{3}{|c|}{ Corrected data using pooled correction factors } \\
\hline \multirow[t]{2}{*}{$\mathrm{W}_{\mathrm{cln}}$} & $r=0.972 *$ & $r=0.972^{*}$ \\
\hline & $r_{c}=0.995^{*}$ & $r_{c}=0.999 *$ \\
\hline $95 \% \mathrm{CI}$ for $r_{c}$ : & $0.995-0.996$ & 0.999-0.999 \\
\hline
\end{tabular}

value of the slope may be dependent on the processing technique. Sample-to-samplevariation is easy to control within each investigator's laboratory, but uniformity is less certain between investigators. Therefore, the value we calculated for $b$ may not be universally applicable. The use of $\mathrm{W}_{\text {pre }}$ or $\mathrm{W}_{\text {par }}$ avoids any such errors.

\section{ACKNOWLEDGEMENTS}

We thank Peter Borst and Vanessa Vargas for technical assistance. This research was supported in part by grants from USDA-NRICGP (\#9601786), New York State Dept. of Agriculture and Markets (\#C970001), Hatch (NYC-\#139-6431) and the Organic Farming Research Foundation to NWC.

Résumé - Détermination rapide du nombre d'acariens Varroa destructor, parasite de l'Abeille domestique (Apis mellifera), à l'aide de plateaux collants. Nous avons mis au point une nouvelle méthode pour estimer le nombre d'acariens Varroa destructor Anderson \& Truman sur un plateau collant sans sous-échantillonnage ; un plateau collant (Calderone et al., 1997) a été enduit d'une fine couche de VaselineTM, attaché à un cadre grillagé pour empêcher l'accès des abeilles, et placé dans une colonie fortement infestée. Des bandelettes CheckMite+ $(10 \%$ de coumaphos) ont été placées dans la colonie pour tuer les acariens qui ont été récoltés ensuite sur le plateau collant. Au bout de quelques jours le plateau 
a été retiré de la colonie. Les acariens, ainsi que les débris et la vaseline, ont été ôtés du plateau à l'aide d'une lame de rasoir à un seul bord tranchant et placés dans un bécher de $150 \mathrm{~mL}$. Nous avons ajouté environ $60 \mathrm{~mL}$ d'hydroxyde de potassium et porté la solution à l'ébullition. Une fois la majorité du matériel non chitineux dissous, nous avons versé la solution dans un filtre en inox et rincé les acariens à l'eau chaude sous le robinet durant 1 min environ. Le filtre a été ensuite plongé dan un bécher de $1000 \mathrm{~mL}$ renfermant $800 \mathrm{~mL}$ d'acétone, puis dans $800 \mathrm{~mL}$ d'hexane à température ambiante pour éliminer les composés solubles polaires et non polaires restants. Le résidu dans le filtre était maintenu $1 \mathrm{~min}$ dans chaque solvant et agité doucement. Il a été ensuite transféré dans une boite de pétri, séché à l'air, pesé $(0,0001 \mathrm{~g})$. La procédure a été répétée avec 32 colonies. Pour chaque échantillon, trois poids ont été obtenus : (1) le poids après le traitement au solvant (poids avant nettoyage $=\mathrm{W}_{\text {pre }}$ ), (2) le poids après avoir éliminé la majorité des éléments impuretés (poids après nettoyage partiel $=\mathrm{W}_{\text {par }}$ ) et (3) le poids après avoir séparé les acariens de toutes les impuretés restantes (poids propre $=\mathrm{W}_{\mathrm{cln}}$ ). Le nombre d'acariens sur chaque plateau a été déterminé par comptage. La régression du nombre d'acariens dans un échantillon sur $\mathrm{W}_{\mathrm{cln}}$ était significatif $(P<0,0001)$. Nous avons donc étudié si $\mathrm{W}_{\text {pre }}$ et $\mathrm{W}_{\text {par }}$ pouvait remplacer $\mathrm{W}_{\mathrm{cln}}$ car ils sont beaucoup plus faciles à obtenir, alors qu'il peut falloir plusieurs heures pour obtenir $\mathrm{W}_{\mathrm{cln}}$. Nous avons calculé la concordance des coefficients de corrélation $\left(r_{c}\right)$ pour $\mathrm{W}_{\text {cln }}$ avec à la fois $\mathrm{W}_{\text {pre }}$ et $\mathrm{W}_{\text {par }}$. Parce que les valeurs de $r_{c}$ étaient $<0,80$, les facteurs de correction pour les deux suppléants ont été calculés en divisant la valeur moyenne de $\mathrm{W}_{\mathrm{cln}}$ par (1) la valeur moyenne de $W_{\text {pre }}$ ou (2) la valeur moyenne de $W_{\text {par. }} W_{\text {pre }}$ et

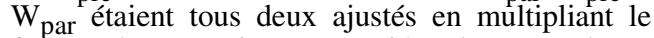
facteur de correction approprié et la concordance des coefficients de corrélation était recalculée. Les valeurs de $r_{c}$ pour les données corrigées étaient toutes $>0,99$. Notre méthode permet d'obtenir en 20 à 30 min une estimation précise du nombre d'acariens présents dans un échantillon, quel que soit le nombre d'acariens présents, et devrait se montrer utile lorsque le nombre d'acariens sur un plateau dépasse 4500. Notre méthode évite aussi la perte de précision qui existe avec les autres méthodes basées sur le sous-échantillonnage.

Varroa destructor / Apis mellifera / estimation de la population

Zusammenfassung - Schnelle Bestimmung der Anzahl von Varroa destructor, einer parasitischen Milbe der Honigbiene Apis mellifera auf klebrigen Unterlagen. Wir entwickelten eine neue
Methode, um die Anzahl der Milben (Varroa destructor Anderson \& Trueman) auf einer klebrigen Unterlage insgesamt ohne Teilzählungen zu schätzen. Die Unterlage war dünn mit Vaseline ${ }^{\mathrm{TM}}$ (Petrolatum) bestrichen und durch ein Gitter vor Einwirkung durch Bienen geschützt. Sie wurde unter ein mit Milben befallenes Volk geschoben (Calderone et al., 1997). CheckMite+ Streifen (10\% Coumaphos) wurden in das Volk gehängt, um die Milben zu töten, die dann auf der klebrigen Unterlage gesammelt wurden. Nach mehreren Tagen wurde die Unterlage aus dem Volk entnommen. Die Milben wurden mitsamt dem Gemüll und der Vaseline mit einer einseitig scharfen Rasierklinge von der Unterlage entfernt und in einem $150 \mathrm{~mL}$ Becherglas gesammelt. Wir fügten etwa $60 \mathrm{~mL}$ 1.0 M Kaliumhydroxid hinzu und kochten die Lösung auf. Nachdem sich das meiste des nicht chitinösen Materials gelöst hatte, siebten wir die Milben in einem rostfreien Stahlfilter aus und spülten die Milben anschließend etwa 1 Minute unter fließendem heißen Wasser. Danach wurde der Rückstand im Filter bei Raumtemperatur in $800 \mathrm{~mL}$ Aceton in einem $1000 \mathrm{~mL}$ Becherglas und anschließend in $800 \mathrm{~mL}$ Hexan getaucht. Dadurch wurden die verbliebenen löslichen polaren und unpolaren Verbindungen entfernt. Der Filter verblieb jeweils eine Minute unter leichtem Rühren. Der verbliebene Rückstand wurde in eine Petrischale überführt, an der Luft getrocknet und gewogen $(0,0001 \mathrm{~g})$. Wir führten diese Prozedur mit 32 Völkern durch. Es wurden für jede Probe 3 Gewichte ermittelt: (1) das Gewicht nach Reinigung mit den Lösungsmitteln (Gewicht nach Vorreinigung $\left.=\mathrm{W}_{\text {pre }}\right)$; (2) das Gewicht nach Entfernung des größten Teils der Verunreinigung (Gewicht nach Teilreinigung $=\mathrm{W}_{\text {par }}$ ); und (3) das Gewicht nach Entfernung aller Verunreinigungen (Gewicht nach Gesamtreinigung $=\mathrm{W}_{\mathrm{cln}}$ ). Die Anzahl der Milben wurde durch ihre Zählung auf der Unterlage bestimmt. Die Regression der Milbenzahl auf die gereinigten Gewichtsproben $\left(\mathrm{W}_{\mathrm{cln}}\right)$ war siginifikant $(P<0,0001)$. Deshalb untersuchten wir, ob $\mathrm{W}_{\text {pre }}$ und $\mathrm{W}_{\text {par }}$ ) als Ersatz für $\mathrm{W}_{\text {cln }}$ geeignet sind. Diese Werte sind schnell und leicht zu bestimmen, während es mehrere Stunden benötigen kann um das Reingewicht $\mathrm{W}_{\text {cln }} \mathrm{zu}$ erhalten. Wir berechneten die Übereinstimmung des Korrelationskoeffizienten für $\mathrm{W}_{\mathrm{cln}}$ mit beiden, $\mathrm{W}_{\text {pre }}$ und $\mathrm{W}_{\text {par. }}$ Da die Werte für $r_{c}<0,80$ waren, wurden Korrekturfaktoren für beide Ersatzwerte durch Teilung des Mittelwertes von $\mathrm{W}_{\mathrm{cln}}$ durch (1) den Mittelwert von $\mathrm{W}_{\text {pre }}$ oder (2) durch den Mittelwert von $\mathrm{W}_{\text {par }}$ berechnet. Beide Gewichte $\mathrm{W}_{\text {pre }}$ und $\mathrm{W}_{\text {par }}$ wurden durch Multiplikation mit den entsprechenden Korrekturgrößen angepasst. Danach wurde die Übereinstimmung der Korrelationskoeffizienten noch einmal berechnet. Die $r_{c}$ Werte für die korrigierten Daten waren alle $>0,99$. Unsere Methode 
ermöglicht uns eine genaue Bestimmung der Milbenzahlen einer Probe innerhalb von 20-30 Minuten, unabhängig von der vorhandenen Anzahl an Milben. Sie sollte besonders nützlich sein, wenn die Anzahl der Milben auf der Unterlage mehr als 4500 Milben beträgt. Unsere Methoden vermeiden den Verlust an Genauigkeit, die bei Methoden basierend auf Zählungen von Teilmengen entstehen.

Varroa destructor / Apis mellifera / Populationsschätzung

\section{REFERENCES}

Anderson D.L., Trueman J.W.H. (2000) Varroa jacobsoni (Acari: Varroidae) is more than one species, Exp. Appl. Acarol. 24, 165-189.

Calderone N.W. (1999) Evaluating subsampling methods for estimating numbers of Varroajacobsoni mites (Acari: Varroidae) collected on sticky-boards, J. Econ. Entomol. 92, 1057-1061.
Calderone N.W., Turcotte R. (1998) Development of sampling methods for estimating infestation levels of Varroa jacobsoni (Acari: Varroidae) in colonies of the honey bee, Apis mellifera (Hymenoptera: Apidae), J. Econ. Entomol. 91, 851-863.

Calderone N.W., Wilson W.T., Spivak M.S. (1997) Evaluation of plant extracts for control of the parasitic mites Varroa jacobsoni (Acari: Varroidae) and Acarapis woodi (Acari: Tarsonemidae) in colonies of Apis mellifera (Hymenoptera: Apidae), J. Econ. Entomol. 90, 1060-1086.

I-Kuei Lin L. (1989) A concordance correlation coefficient to evaluate reproducibility, Biometrics 45, 255-268

I-Kuei Lin L. (1992) Assay validation using the concordance correlation coefficient, Biometrics 48, 599-604.

Ostiguy N., Sammataro D. (2000) A simplified technique for counting Varroa jacobsoni Oud. on sticky boards, Apidologie 31, 707-716.

SAS Institute Inc. (1988) SAS/STAT ${ }^{\mathrm{TM}}$ User's Guide, Release 6.10 Edition, Cary, NC, SAS Institute, Inc. 